\title{
Decentralization as a Strategy for improving Service delivery in the Botswana Public Service Sector
}

\author{
Theophilus Tebetso Tshukudu \\ Lecturer \\ University of Botswana, Department of Political Science and Administrative Studies \\ Private Bag UB00705, Gaborone, Botswana \\ Tel: +267 3554169, Fax: +267 3170706, Email: theophilus.tshukudu@ mopipi.ub.bw
}

Accepted: May 15, 2014

Doi:10.5296/ jpag.v4i2.5719 URL: http://dx.doi.org/10.5296/ jpag.v4i2.5719

\begin{abstract}
The Botswana public Service has been faced with service delivery challenges since independence in 1966. Like other developing and under developed countries, the Botswana government has reviewed its service delivery processes and initiatives with a view to better productivity across the public service sector. Many strategies and initiatives were introduced by the Botswana government over a long period of time to mitigate poor service delivery across the public service sector. One of these initiatives were the decentralization of certain functions from central to local government. However, the implementation of this initiative was not without problems. This paper will highlight the decentralization in general terms will be discussed and the focus will be narrowed to how decentralisation has to improved public service delivery in the public service sector. The evaluation of the process will be highlighted; recommendations and closing remarks will be made.
\end{abstract}

Keywords: Service delivery, decentralisation, Botswana, public service, government 


\section{Introduction}

The Botswana public service has grown by leaps and bounds since independence in 1966. The public service sector accounts for about a third of the total employment and central government is the single largest employer in the country. According to recent statistics total employment in the Botswana Public service stands at around 100000 (Department of Central Statistics 1998, p.97). The statistics indicate that government employs about 82000 and local authorities employ about 18000 people. According to Mogalakwe (2004, p.21), the public service has grown tremendously compared with the 9,000 at independence. He further poses the question of whether the management style is changing or is still that of 1966 and if so how has this situation impacted on service delivery over the years. While the public service has expanded steadily over the years the following problems have emerged: absenteeism and lateness to work, poor public relations, and outright public criticism have been posing serious challenges to management. This trend has affected the government's efforts to improve the economic and social well-being of the public. The national economic development does not only depend on natural resources but the quality of the public services rendered is also equally important and can therefore, not be overemphasized. There is therefore a need to improve productivity in the Botswana Public service.

\section{Definitions}

According to Cheema and Rondenelli (1983, p.137), decentralisation is the transfer or delegation of the legal and political authority to plan, make decisions and manage public functions from the central government and its agencies to field organisation of those agencies, subordinate units of government, semi-autonomous public corporations or regional development authorities, autonomous local governments, or non- governmental organisations.

A system of democratic decentralisaion has to be so organised that the relations between central and local government reflect a balance between centralisation and decentralisation of authority and functions. Cheema and Rondella (1983, p.139) note that, while the central government has to delegate some of its authority, and encourage autonomy of local authorities, it has to continue to retain some responsibilities relating to control, direction, supervision and guidance, particularly during the infant stage of development of local authorities.

Central government has to retain the function which local government may not be able to undertake due to the magnitude of resources or expertise required. It may have to provide the local government with financial and manpower resources and technical assistance of different kinds without which these bodies may not be able to perform their functions. It may have to direct these bodies on the nationally defined priorities for the utilisation of scarce resources. Some central controls may be required for maintaining nationally accepted standards of performance and integrity and for the sound management of finances. Over and above all, central controls have a role in developing administrative capacities of local institutions through various measures which could include training, manpower development and gradually increasing autonomy (Cheema \& Rondenelli 1983, p.138). 
Democracy, decentralisation, public participation and accountability have been considered to be objectives of good governance in Botswana. Decetralisation is a key factor in realising the Botswana national principles of self-reliance, unity, development and democracy, which have guided the country's social, economic and political development since independence in 1966. In 1997, Botswana adopted a Long Term Vision for Botswana (Vision 2016) with the theme "Towards Prosperity for all". The vision 2016 ideals include "building an open, democratic and accountable nation". Decentralisation may contribute significantly to attaining this ideal. Efforts to strengthen democracy and good governance in the country have to be complemented by invigorating the institutions as well as the decentralisation process (BIDPA Report 2003, p.8). Phirinyane (2009, p.156) states that the role of government is to serve as an instrument of democratic decentralisation, development and good governance. He adds that throughout Africa, moves are being made to give more power to the people at grass roots level. The government decentralises for its geographical, social, political, economic and administrative advantages and creates organisations of local government and administration. Mogalakwe (2004, p.56) points out that certain geographical features such as the size and underdeveloped communication and infrastructure facilities in the country create the need for decentralisation. Decentralisaion could also facilitate the administration of societies with cultural and social heterogeneity and it could promote national unity by accommodating the demand from diverse groups for political participation and limited self-government. Phirinyane $(2009$, p.60) observes that by resorting to decentralisation, the national development plan could come closer to the felt needs, problems and priorities of the people. Administrative decentralisation could reduce the concentration of authority in the central government; promote decongestion of activities from the centre to the periphery. It could relieve the central government bureaucracy of involvement in purely local issues, check excessive and straight-jacketed central directives, reduce delays, and introduce speed in decision making.

\section{Research methodology}

The methodology used to compile this paper was mainly through secondary data, primarily because this method ample research material in adequate for the researcher to use in his area research and also due to the fact that collecting data is simply and convenient for the researcher given the amount of time required collecting such data (Struwig\& Stead, 2001). The authors further note the importance of internet as source of data collection in that it is faster and such it allows the researcher to access varied yet complementing information which will ideally help the researcher to make an Informed view point on the issue or debate they are researching on. Over and above the internet, data was also collected from the Botswana public service documents such as directives, manuals, policy documents, regulatory handbooks and through various government reports and through the existing literature in books.

\section{The rationale for decentralisation}

Phirinyane (2009) is of the view that decentralisation, in its various forms, has been adopted by both developed and developing countries alike as a central public sector reform strategy. 
For developing countries decentralisation is not only a reform strategy but it is increasingly seen as an integral part or a sine qua non of the development process. Although political or fiscal decentralisation is not necessarily associated with New Public Management, managerial decentralisation is, and NPM and decentralisation tend both to feature on any notional list of the reform agenda for the public services of developing countries. From this it might be assumed that the two, whilst by no means inseparable, areclosely related - although as the present article will demonstrate this relationship is far from simple.

\section{Botswana's accomplishment and progress towards decentralised governance}

According to Phirinyane (2009), the reasons for decentralisation are varied and may include; demand for local level democratic control and autonomy, the perceived economic, administrative and political advantages of decentralisation, post conflict reconstruction, interests of local and national political elites, and demand from the World Bank and other donor agencies (Devas and Delay, 2006: 678-79). Popular participation in the development process and decision-making has been cited as one of the main reasons for decentralisation (Mawhood, 1983). Whatever the reason(s) for decentralisation and the form (e.g. devolution or deconcentration) it may take, the main point is to provide efficient and effective local services for human development. Decentralisation is a complex process and it is a product of the context within which it is taking place (Smoke, 2003). In Africa there are many hurdles against meaningful decentralization, but quite often it is the legal and institutional aspects that influence the eventual outcome of decentralization (Wunsch, 2001). The situation has been exacerbated by the weakly conceived decentralization legislation, poorly trained local personnel, poorly designed local institutions and limited financial resources(Mawhood, 1983; Wunsch, 2001; Olowu and Wunsch 2004).

Botswana established a democratic political framework after independence and developed local government structures below the central government level. A number of features stand out in Botswana's experience with decentralisaion. The country has run its administration under a democratic political framework since independence. Although Botswana has produced a holistic, overarching, cross-sectoral decentralisation policy statement, several initiatives have been undertaken by the government to decentralise functions and authority. According to The government has also established the enabling conditions (policies and practices) from 1964 onward that promote decentralisation. In 1964, two years prior to independence, a government white paper expressed the government's commitment to decentralisation through the elected rural urban councils. Various presidential commissions such as Organisation \& Management review; consultancy reports and inter-ministerial committees have examined the question of decentralisation and recommended reforms. As a result the government has undertaken decentralisation of administration, personnel and finances for both local government and within the central government itself (Mothusi 2008).

\section{Administrative decentralization to district administration}

The office of the District Commissioner has operated as a representative of central government in the district from the pre-independence days. It was strengthened with additional and primary responsibility for the co-ordination of rural development and 
decentralised district level development planning. In addition to the above organisations of administrative decentralisation, the country has established a development planning machinery at district level and six development plans have been formulated so far against nine national development plans. Procedures for the formulation, implementation and monitoring of district plans are in place and are being constantly improved (Mothusi 2008).

\section{Challenges in promoting decentralisation}

Bardhan (2002) as cited by Phirinyane (2009) notes that decentralisation has for many decades been seen as a publicsector reform necessary for invigorating the state. The apparent global popularity of decentralisation may be attributed to the perceived failure of centralisation. Some of the factors that prompt nations to adopt decentralisation are the anticipated 'improved efficiency, improved governance, improved equity and improved development and poverty reduction' (Smoke, 2003: 9, 10). In Mawhood's words decentralisation '... suggests the hope of cracking open the blockages of an inert bureaucracy', and 'curing managerial constipation...' (1983: 1). Advocacy of decentralisation as a cure for bureaucracy's ills thus predates New Public Management. However, the association between the two concepts may be seen as a result of the emergence of privatisation arguably the defining component of NPM, as one of four types of decentralisation, according to Lister and Betley's classification (Phirinyane 2009).

In spite of the above positive attributes, the country faces difficult constraints and challenges in enhancing the effectiveness of decentralisation in the institutions of local government. These constraints and challenges relate to the limitations of human and financial resources, public participation and central-local government co-ordination in development planning and management. Shortage of qualified staff is a major constraint on local government. There is widespread concern about the continuing shortage of qualified staff in district and local level organisations and the quality of training available to them. The government assumes the responsibility for human resources development in the country and efforts have been made by strengthening educational and training programmes (Botswana Daily News (2007). There has been a large expansion in the capacity of primary, secondary and tertiary institutions. Pre-service and in-service training programmes have been introduced and/or strengthened. More concentrated efforts are however needed for human resources development in district and local government level organisations. Bakwena(2006, p.47) notes that besides the need for strengthening education and training, local authorities require a personnel management system and service conditions that can attract, retain and motivate staff of good calibre. Local authorities continue to lose qualified staff to competitors in the labour market. Innovative measures could help in retaining deserving staff and in keeping them motivated. Mogalakwe further adds that the decentralisation of the human resources function has been problematic, especially when it comes to council employees. People are unwilling to work in rural areas and councils lack attractive benefits to lure them to be transferred to rural areas. More specifically, people with skills are attracted to work for the private sector in urban areas. The shortage of qualified and skilled staff thus accounts for poor service delivery by the councils. In some districts, especially in the central, where there has been considerable decentralisation to the sub-districts, decentralisation of responsibilities was not matched with the provision of 
necessary staff and capacities. Skilled personnel were retained at the centre, leaving the sub-districts with inexperienced and poorly qualified staff, and yet that is where services are provided. The headquarters retains most of the skilled and yet there is minimal actual work (Mpabanga 2005, p.123).The introduction of the Performance Management System (PMS) is one of the major decentralisation initiatives introduced by the government. District officers had little to say about the PMS, which is only now 2006 being introduced to local authority councils, although the PMS was initiated in 1997 in the central government. There are no substantive comments from districts on whether it had an impact on councils' service delivery. But one of the views held by lower and middle managers in the local government are that the performance management system is impractical, given that it aimed at changing work practices but not the officials' attitudes. Negative work attitudes were at the root of inefficiency and ineffectiveness (DPSM 2003, p. 92).

The work environment is also such that planning may be done, but implementation tends to be problematic because of constant diversions and 'emergencies" that officials had to attend to. Other key informant views are that even though the PMS is supposed to encourage decentralisation, it is not backed by the decentralisation of decision making to lower and middle management levels (e.g. in career progression and performance rewarding of subordinates). The central government still exercises considerable control over human resource functions and rewarding systems and by so doing defeats the goals of the PMS.

Against the backdrop of the continued decline in performance of the local government, the government assigned the Botswana Institute for Development Policy Analysis (BIDPA) to assess the decentralisation of performance improvement initiatives at local government level. The Botswana Institute for Development Policy Analysis (BIDPA) was commissioned by the United Nations Development Programme (UNDP) to undertake a review of the decentralisation initiatives in Botswana (Project BOT/02/M03/A/MX). This report deals with component number four of the project, which is the assessment of the impact of the decentralisation initiatives on the intended beneficiaries. As the decentralized organisations are at the forefront of the implementation of decentralisation initiatives, the major thrust of the research was to assess the effectiveness of these organisations in service provision (BIDPA Report 4, 2003, p.5).

\section{Evaluation of the Botswana decentralization process}

The report based on a questionnaire that was randomly administered to about a thousand people across the country, also draws on key informant interviews of public officers at district and central government levels. The aim of the questionnaire was to determine the people's perceptions of the effectiveness of government's decentralisation initiatives, through local authority provision of services. The key informant interviews were designed to seek perceptions and views about service provision, from officers that are involved in the provision of services in the rural areas.

This project thus aimed at examining the effects of decentralisation service provision on the intended beneficiaries. The beneficiaries are ordinary people or members of the communities whose perceptions on the effectiveness of the government's decentralisation initiatives were 
sought. The intention was to determine the respondents' perceptions of whether any improvement to their wellbeing could be attributed to decentralisation, especially in regard to access to service, and their efficient and effective provision. The next section summarises the responses of the key informants to questions regarding the objectives, design and strategy of decentralisation; implementation of decentralisation initiatives; the effectiveness of decentralised service provision and the future direction of decentralisation in Botswana (DPSM 2004, p.89).The objectives and the strategies for achieving decentralisation are not clearly defined or specified. Despite an enabling democratic political tradition, and several decentralisation initiatives, Botswana does not have a holistic, overarching, cross-sectorial decentralisation policy statement. It is unclear what decentralisation is supposed to achieve, its direction, targets and goals. Hence the decentralisation process appears to ad hoc, unintegrated and uncoordinated. Decentralisation by the central government to lower levels appears illusive. Some of the functions that are ostensibly decentralised to the local authorities are actually not, or are only partially so. These include financial management, human resources management, and management of information technology services. Views on the attainment and effectiveness of the decentralisation process are doubtful even though the process is regarded as important for improving productivity, efficiency and the effectiveness of service delivery at local government level. The reasons for this low attainment of decentralisation objectives differ significantly between district and central officerswhereas the district officers emphasised that major constraints were centralised control and inadequate local resources and authority, central government respondents laid the blame on decentralization organisations' capacity constraints and negative attitudes. To most district level officers, the lack of localised revenue collection (and utilisation) in the council areas of jurisdiction appears to be the stumbling block towards an effective decentralisation process (Bhatta2000).

\section{Recommendations}

This paper recommends that the following must be addressed for the successful implementation of the decentralization process:

1. The Botswana government is charge with a mandate to provide the relevant policy document that will act as temple for all stakeholders for the successful implementation of decentralisation across the entire public service. In the absence of such policy document, implementers would find it difficult to meaningfully address the various aspect of the decentralization process. One other advantage of having a policy on decentralization is that consistency is guaranteed across the public service including at lower levels of government.

2. The government of Botswana must do away with centralized control of the decentralization process and most importantly, public sector managers must be adequately be trained on how decentralisation process ought to be implemented. The Botswana government should adequately deal with the issues of capacity constraints and negative attitudes as these they negate against and effective and efficient service delivery through the implementation of decentralization. 
3. The Human resource plays a critical role in the implementation of decentralization as a strategy to improve service delivery central government but most importantly local government where service delivery is needed most.

4. Decentralization by central government to local authority must be done in earnestly and with strategic plan in place for its implementation. The central government must ensure through its various mechanism the effective cascading a culture of ownership and custodianship by the local authority on issues of decentralization.

\section{Conclusion}

From the above discussion, it may be concluded that there is a general perception that for the benefits of decentralisation to be fully realized, the implementation process must be optimal. The objectives, and the strategy for implementation, must be clear. Also, the human and material resources must be available at local level. Importantly, managerial and technical capacity must be built for decentralisation. In addition, there must be regulatory mechanisms and safeguards against possible abuse of the system.

\section{References}

Bakwena F. (200 ). Productivity in the Botswana Public service.Botswana public service Journal.Vol 3 no 6 pp12-17

Bhardan (2002).Decentralisation of local Governance in Developing Countries: A comparative Perspective

Bhata, B, D. (2000). "Decentralisation in the Context of Good Governance and Civil Society in Nepal".In Public Administration Journal.Vol x \& xi, (pp.368-375). Kathmandu: Public Administration Campus.

Botswana Daily News (2007).Productivity as a Tool for Competitiveness.Gaborone: Government Printer.

Botswana Institute of Policy Development Analysis Report 2003. Gaborone. Government Printer.

Cheema, N., \&Rondelli, J., L. (1983). Using evaluation of training and development. London. Kogan Page.

Directorate of Public Service Management. (1998). Botswana public service performance : A challenge to leadership. Government Printer.

Directorate of Public Service Administration (2008). Human Resource management guidelines: DecentralisedFunctions. Gaborone: Government Printer

Lister, S. \&Betley, M. (1999).Approaches to Decentralisation in Developing Countries. Paper presented as background reading for the MEFMI/DFID workshop on Good Practice in Public Expenditure Management. Accessed at www.sti.ch/pdfs/swap252.pdf on 05/02/2013 


\section{Macrothink \\ Journal of Public Administration and Governance ISSN 2161-7104 2014, Vol. 4, No. 2}

Mawhood, P. (1983).Local Governance in the Third World. The experience of Tropical Africa: Chichester.John Wiley \& Sons Ltd.

Mogalakwe M. (2004). Improving labour Productivity in Botswana: Gaborone. Morula Printers.

Mothusi, B. (2008). Public Sector Reforms \& Managing Change in Botswana: The Case of Performance Management System.

Mpabanga, D (2008). Human Resource in the Botswana Public Service Sector. CapeTown. Oxford.

Olowu, D. and Wunsch, J., S. (eds). (2004) Local Governance in Africa: The Challenges of Democratic Decentralisation.Boulder. Lynne Reinner Publishers, Inc.

Phirinyane, M. (2009).Human Resource Management \&Decentralisation in Botswana \& South Africa.

Smoke, P. (2003).Decentalisation in Africa.Goal, Dimensions, Myth \& Challenges.Journal of Public Administration \& Development.Vol 23 no 1 pp 7-16.

Struwig, F. W., \&Stead, G.B., (2001).Planning, Designing and Reporting Research. Cape Town: Peterson education South Africa 